\title{
Effects of different levels of feeding of pistachio epicarp silage on wool characteristics of growing Afshari lambs
}

\author{
Mahnaz Salehi ${ }^{1}$, Farhad Mirzaei $^{{ }^{*}}$, Ali Mahdavi $^{2}$ \\ ${ }^{1}$ Animal Science Research Institute of Iran, Karaj, Iran; *Corresponding Author: farmir2003203@yahoo.com \\ ${ }^{2}$ Faculty of Veterinary Medicine and Animal Husbandry, Semnan University, Semnan, Iran
}

Received 18 January 2012; revised 22 February 2012; accepted 16 March 2012

\begin{abstract}
Sixteen Afshari male lambs (mean live weight $35 \pm 1.21 \mathrm{~kg}, 10$ month of age) were used to study the effect of different levels of pistachio epicarp silage $(0 \%, 8 \%, 17 \%$ and $25 \%)$ on wool characteristics. The fleece weight (FW), staple length on shoulder (STS), flank (STF), back (STB) and rump (STR), true wool fiber (TW), modulated fiber (MF), kemp fiber (KF) percentage, mean wool fiber diameter (MD) and its coefficient variation (CVMD), breaking load (BL), wool tenacity (WT) and extension (E) were measured. These data were analyzed by one-way ANOVA using SAS software package. The total mean of FW, STS, STB, STF STR; TW, MF, KF, MD, CVMD, $B L, W T$ and $E$ of wool were $1622.2 \pm 0.2 \mathrm{gr}, 6.20 \pm$ $0.26 \mathrm{~cm}, 6.80 \pm 0.20 \mathrm{~cm}, 6.50 \pm 0.20 \mathrm{~cm}, 6.90 \pm$ $0.20 \mathrm{~cm}, 63.30 \pm 1.6 \mathrm{mu}, 8.30 \pm 1.6 \mathrm{mu}, 28.40 \% \pm$ $2.5 \%, 37.0 \pm 0.9 \mathrm{mu}, 47.02 \% \pm 2.99 \%, 7.60 \pm 0.3$ kgf, $3.40 \pm 0.2 \mathrm{gf} /$ tex and $31.1 \% \pm 1.7 \%$ respectively, although there was significant difference among treatments on FW, MF, KF, MD, BL and WT. The results showed that feeding lambs with $25 \%$ pistachio epicarp silage of total dry matter intake affected wool characteristics and its effect was similar with the control group.
\end{abstract}

Keywords: Afshari Lamb; Pistachio Epicarp Silage; Wool Characteristic

\section{INTRODUCTION}

Pistachio by-product has potentially high nutritive value but its biological effects in ruminants have not been studied extensively. Iran is one the main pistachio producers in the world. There is about 298939 hectares of pistachio garden in Iran and annual pistachio production is 307036 tones [1]. Pistachio by products usually has some anti nutritional substances such as tannin, which have different effects on animal performance [2]. The total phenolic substance reported is 6.4\% [3]. Tannins in feeds may have positive nutritional effects, but at high level, it may inhibit microbial activity of rumen and thereby, reduces the microbial production. High level of tannin in feed (50 - $100 \mathrm{~g} / \mathrm{kg} \mathrm{DM}$ ) reduce DM intake and digestibility of DM, Thereby the result is reduction of daily gain and wool production, but at lower level (20 $40 \mathrm{~g})$ has beneficial effects for animals [4,5]. This experiment was conducted to determinate of effect of feeding different levels of pistachio epicarp silage, that containing high levels of tannins, on quality and quantity characteristics of Afshari lambs wool.

\section{MATERIAL AND METHODS}

Four groups of fattening male lambs (age 10 months, initial live weight $35.9 \pm 1.21 \mathrm{~kg}$ ), were fed for 90 days, iso-caloric, iso-nitrogenous diets, containing either no added pistachio epicarp silage (control) and added levels $8 \%, 17 \%$ and $25 \%$ pistachio epicarp silage (based on dry matter) in rations. Dry matter (DM), crude protein (CP) and organic matter (OM), determined [6]. Van Soest and Robertson's method [7] was used to analyze neutral detergent fibre (NDF). Total phenolic compounds [8], total tannins [9] were determined. Crude protein degradability by nylon bag method [10] and in vitro gas production test for samples were determined [11]. Tilley and Terry's methods were used to determine in vitro dry matter digestibility (IVDMD) of silage samples [7]. In vitro dry matter digestibility and Gas production were used to estimation metabolism energy. The staple lengths of the shoulder, back, flank and rump were determined and greasy fleece weight measured at the end of experiment. Wool samples of about $20 \mathrm{~g}$ were taken just before shearing from right mid-side fleeces of each ewe. Three or four locks were randomly chosen from area throughout each sample. Locks from each sample were individu- 
ally washed with hot water $\left(45^{\circ} \mathrm{C}\right)$ water and a non-ionic detergent, rinsed in hot water, and then dipped in a commercial solvent (dichloromethane alcohol) to remove any residual grease not removed in washing. Care was taken to avoid disturbing the staple formation of the fibres and to minimize the loss of shorter fibres in the samples. Samples were then air-dried overnight. Small amounts of wool Samples were separated as sub samples for wool fineness analyses and other sub sample for measuring the tenacity and different fibre types in carpet wool. The first sub sample was prepared for measurement with the projection microscope technique in accordance with ASTM D2130-78 short-section procedure to determine fibre diameter [12]. Each sample was compressed and fibres were cut at mid-staple with a heavyduty cross-section device to provide snippets 200 - 300 $\mu \mathrm{m}$ in length. Over one hundred fibres from each sample were measured. Mean fibre diameter and standard deviation were obtained for each sample and the CV was calculated. Visual subjective test was used to separate the various fibre types, including true wool, modulated, Kemp and coloured fibres. Then the samples were subjected to the benzoyl test.

The sub sample was paralleled in fibro liner component of Almeter. However, after that a sufficient number of fibers so that, after combing, an aligned specimen of 15 to $25 \mathrm{mg}$ is available for testing. The paralleled fibers were comb the protruding end with the coarse comb to remove loose fibers and foreign material and to secure partial parallelization of the fibers. Reverse the tuft and repeat the combing on the other end. The clamped tuft were placed in the grips of tensile testing machine (Instron) and used $1 \mathrm{~N}$ capacity load cell with the pulling clamps moved at $25 \mathrm{~cm} / \mathrm{mm}$. after recorded the breaking load, the broken fibers weighed to the nearest $0.0001 \mathrm{~g}$ and Breaking tenacity calculated using Eq.1 [13,14].

$$
\text { Breaking tenacity, gf/Tex }=(\mathrm{b} / \mathrm{M}) * 2 / 54 \times 10^{-5}
$$

where $\mathrm{B}=$ bundle breaking load in gf. and $\mathrm{M}=$ bundle mass (g).

The following model was used for statistical analysis by one-way design and ANOVA using SAS software package [15].

$$
\gamma_{\mathrm{ik}}=\mu+\alpha_{\mathrm{i}}+\varepsilon_{\mathrm{jk}}
$$

where $\gamma_{\mathrm{ik}}$ is individual records on every trait $\alpha_{\mathrm{i}}$ is the effect of $\mathrm{i}^{\text {th }}$ treatment and $\varepsilon_{\mathrm{jkm}}$ is the residual effect.

\section{RESULT AND DISCUSSION}

Although there were high range of differences among treatments but the results showed significant differences among treatments on fleece weight, fiber diameter, modulated and kemp fibers percentage, breaking load and tenacity (Table 1). Some important traits such breaking load and tenacity were improve from $6.9 \mathrm{~kg}$ and 3.1 gf/tex in first treatment (0 levels) to $8.5 \mathrm{~kg}$ and $3.7 \mathrm{gf} / \mathrm{tex}$ in high level (25\% pistachio epicarp silage level). There were not studies about effect of pistachio epicarp silage intake on fiber performances. The studied on pistachio

Table 1. Effects of different levels of dried pistachio epicarp silage (PES) on wool characteristics of growing

\begin{tabular}{|c|c|c|c|c|c|c|c|}
\hline \multirow{2}{*}{\multicolumn{2}{|c|}{ Traits }} & \multicolumn{4}{|c|}{ Treatment (\%PES in diet) } & \multirow{2}{*}{$\mathrm{SE}$} & \\
\hline & & 0 & 8 & 17 & 25 & & \\
\hline \multirow{4}{*}{$\begin{array}{c}\text { Staple } \\
\text { length }(\mathrm{cm})\end{array}$} & Fleece Weight (g) & 1658.3 & 1133.3 & 1116.7 & 1633.3 & 256.8 & $*$ \\
\hline & shoulder & 5.90 & 6.36 & 6.20 & 6.80 & 0.5 & NS \\
\hline & Back & 6.70 & 6.7 & 7.0 & 7.2 & 0.5 & NS \\
\hline & mid-side & 6.5 & 6.7 & 6.2 & 6.8 & 0.6 & NS \\
\hline & Rump & 5.8 & 6.0 & 5.7 & 5.8 & 0.4 & NS \\
\hline Fiber dia & leter $(\mu)$ & 37.1 & 36.9 & 35.4 & 38.5 & 2.2 & $*$ \\
\hline CV of dia & eter (\%) & 46.7 & 45.5 & 44.6 & 50.6 & 5.2 & NS \\
\hline True w & l (\%) & 63.1 & 64.2 & 63.2 & 62.6 & 4.5 & NS \\
\hline Medullate & fiber (\%) & 8.2 & 4.8 & 15.3 & 5.1 & 3.2 & * \\
\hline Kem & (\%) & 28.6 & 30.9 & 21.4 & 32.3 & 5.7 & $*$ \\
\hline Breaking & oad (kg) & 6.9 & 7.3 & 7.9 & 8.5 & 0.5 & $*$ \\
\hline Tenacit & gf/tex) & 3.1 & 3.4 & 3.5 & 3.7 & 0.4 & $*$ \\
\hline Extens & n (\%) & 31.6 & 32.1 & 31.5 & 28.7 & 4.4 & NS \\
\hline
\end{tabular}
Afshari lambs. 
Table 2. The average total for wool performances of Afshari lamb.

\begin{tabular}{|c|c|c|c|c|c|}
\hline \multicolumn{2}{|c|}{ Traits } & Mean \pm SE & $\mathrm{CV}$ & Min & $\operatorname{Max}$ \\
\hline \multicolumn{2}{|c|}{ Fleece Weight (g) } & $1622.2 \pm 0.2$ & 33.0 & 600 & 2550 \\
\hline \multirow{5}{*}{$\begin{array}{l}\text { Staple Lengths } \\
\text { (cm) }\end{array}$} & Shoulder & $6.20 \pm 0.26$ & 12.8 & 5 & 8 \\
\hline & Back & $6.80 \pm 0.20$ & 12.4 & 5.5 & 9 \\
\hline & Flank & $6.50 \pm 0.20$ & 13.7 & 5.0 & 8.5 \\
\hline & Rump & $6.90 \pm 0.20$ & 12.0 & 5.0 & 7.5 \\
\hline & Mean & $6.60 \pm 0.18$ & 13.5 & 5.0 & 9.0 \\
\hline \multirow{3}{*}{$\begin{array}{l}\text { Fleece Fiber } \\
\text { Contents (\%) }\end{array}$} & True wool & $63.30 \pm 1.6$ & 11.0 & 43.21 & 82.2 \\
\hline & Medullated & $8.30 \pm 1.6$ & 75.8 & 1.58 & 19.8 \\
\hline & Kemp & $28.40 \pm 2.5$ & 34.1 & 10.0 & 43.05 \\
\hline \multicolumn{2}{|c|}{ Mean Fiber Diameter (mu) } & $37.0 \pm 0.9$ & 9.60 & 30.8 & 42.7 \\
\hline \multicolumn{2}{|c|}{ CV of Fibre Diameter (\%) } & $47.02 \pm 2.99$ & 17.8 & 31.34 & 61.6 \\
\hline \multicolumn{2}{|c|}{ Breaking load (kg) } & $7.60 \pm 0.3$ & 13.7 & 5.9 & 10.0 \\
\hline \multicolumn{2}{|c|}{ Tenacity (gf/tex) } & $3.40 \pm 0.2$ & 20.2 & 2.1 & 4.8 \\
\hline \multicolumn{2}{|c|}{ Extension (\%) } & $31.1 \pm 1.7$ & 21.9 & 15.8 & 41.3 \\
\hline
\end{tabular}

epicarp intake has shown that, there were high range of without significant differences among treatments but fiber diameter and kemp fiber percentage were reduce in high level (32\% pistachio epicarp level) to control group [16]. In another research work which has been fed four different levels of pistachio epicarp $(0 \%, 12 \%, 20 \%$ and $30 \%$ of dry matter) to goats, affected growth and cashmere production. The results showed that the highest mean fleece, finer cashmere and more strength were found for diet with $10 \%$ of pistachio epicarp, but the lowest belong to control group. Total fleece weight at the end of experiment was similar [17]. Effect of condensed tannins upon body weight, wool growth and rumen metabolism in sheep grazing Sulla contained 40 - 50 g condensed tannins (CT)/kg DM discussed [18]. They concluded that after chewing during eating, a lower proportion of total CT was readily extractable and greater proportions were protein-bound and fiber-bound, because the action of CT decreased rumen ammonia concentration and decreased molar proportion of bio-butyrate and iso-valerate. At highest growth of wool, CT increased wool growth rate such effect was not observed when wool growth was low. There are not any other projects about effects of feeding pistachio epicarp silage on wool characteristics, but the results of other projects showed that use of feeds containing high levels of tannins like pistachio epicarp result to low performance in fattening lambs feeding pistachio epicarp up to 30 percentage of total ration [1], decreasing in CP degradation in rations [7] and also feeding pistachio epicarp to dairy cattle up to $10 \%$ resulted to decrease in milk yield, lactose and protein\% [19].

\section{CONCLUSION}

It was concluded that nutritional effect due to tannin need to be established using plants containing intermediate tannin concentration (10 - $20 \mathrm{~g} / \mathrm{kg} \mathrm{DM})$. Due to high variation were observed in quality and quantity characteristic of wool (Table 2), it is necessary that feeding experiments such this one do in a long term period because the effects of feeding on wool are slow and time consuming

\section{ACKNOWLEDGEMENTS}

We thank Mr. Eng. M. Afshar, technical wool assistance and Farm staff of Animal Science Research Institute of Iran for providing of necessary facilities to carry out of this research work.

\section{REFERENCES}

[1] Mahdavi, A. (2008) Effects of physical and chemical treatments on quality of pistachio epicarp and lamb performance. Ph.D. Thesis, Tehran University, Tehran.

[2] Decandia, M. (2000) Responses to an ant tannic supplementation by browsing goats. 7 th International Conference Goats, 1, 71-73.

[3] Labavitch, J.M., Heintz, C.M., Rae, H.L. and Kadar, A.A. (1982) Physiological and compositional changes associated with maturation of Kerman pistachio. Journal Ameri- 
can Social Horticulture Science, 107, 688-692.

[4] Brooker, J.D., Klum, D., Miller, S., Skene, I. and Donovan, L.O. (1995) Rumen microorganism as providers of high quality protein. Livestock Research for Rural Development, 6, 1-4.

[5] Kumar, R. and Vaithiyanathan, S. (1990) Occurrence, nutritional significance and effect on animal productively of tannins in tree leaves. Animal Feed Science Technology, 30, 21-38. doi:10.1016/0377-8401(90)90049-E

[6] AOAC (2000) Official methods of analysis. 17th Edition, Association of Official Analytical Chemists, Gaithersburg.

[7] Van Soest, P.J. and Robertson, J.B. (1979) Systems of analyses for evaluation of fibrous feed. Proceeding of International Workshop on Standardization of Analytical Methodology for Feeds, International Development Research Center, Ottawa, 49-60.

[8] Julkunen-Titto, R. (1985) Phenolics constituents in the leaves of northern willos: Methods for the analysis of certain phenolics. Journal of Agriculture and Food Chemistry, 33, 213-217. doi:10.1021/jf00062a013

[9] Makkar, H.P.S., Borrowy, N.K. and Becker, K. (1992) Quantitation of polyphenols in animal feedstuffs. Proceeding of XVI International Conference of Group of Polyphenol, Lisbon, 13-17 July 1992.

[10] Orskov, E.R. and McDonald, I. (1979) The estimation of protein degradability in the rumen from incubation measurements weighted according to rate of passage. Journal of Agricultural Science. Cambridge, 92, 499-503. doi:10.1017/S0021859600063048

[11] Menke, K.H. and Steingass, H.(1988). Estimation of the energetic feed value obtained from chemical analysis and in vitro gas production using rumen fluid. Animal Research Development, 28, 7-55.

[12] Anonym (1982) Breaking strength of wool fibre bundles one IN. Gage length. American Society for Testing Materials (ASTM), Philadelphia, 2130-2610.

[13] Anonym (1982) Diameter of wool and other animal fibres by micro projection. American Society for Testing Materials (ASTM), Philadelphia, 295-302.

[14] Anonym (1982) Standard definition of terms relating to textiles. American Society for Testing Materials (ASTM), Philadelphia, 123-182.

[15] SAS/STAT (1987) User’s guide. 6.03 Editions, SAS Institute Inc.

[16] Salehi, M., Mahdavi, A. and Zahedifar M. (2008) Effect of different levels of dried pistachio epicarp on wool characteristics of growing Afshari lambs. Oman International Conference on Small Ruminants Production and Health in Arid and Semi-Arid Region, Oman, 26-28 January 2008.

[17] Seyed Moumen, S.M., Nik Khah, A., Zahedifar, M. and Salehi, M. (2004) Effect of different levels pistachio by product and its tannins on growth and cashmere production of Raeini goats. Journal of Pajouhesh-va-Sazandegi, 65, 92-101.

[18] Tilley, J.M.A. and Terry, R.A. (1963) Two stage technique for the in vitro digestion of forage crops. Journal of Breeding Grasslands Society, 18, 104-111. doi:10.1111/j.1365-2494.1963.tb00335.x

[19] Memarizade, R. (2007) Effects of pistachio epicaep replacement in Holstein dairy cattle. M.Sc. Thesis, Azad Islamic University, Khorasegan. 